\title{
Influence of Drip Irrigation and Nitrogen Fertigation on Growth Parameters of Onion (Allium cepa L.)
}

\author{
Pooja Rani*, V.K. Batra, A.K. Bhatia and Shiwani \\ Department of Vegetable Science, CCS Haryana Agriculture University, Hisar - 125004, \\ Haryana, India \\ *Corresponding author:
}

\section{Keywords}

Drip irrigation,

Nitrogen,

Fertigation,

Onion

\section{Article Info}

Accepted:

20 November 2018

Available Online:

10 December 2018

\section{A B S T R A C T}

The field experiment was conducted during Rabi season of 2016-17 and 2017-18 at Research Farm of the Department of Vegetable Science, CCS Haryana Agricultural University, Hisar to study the effect of drip irrigation and nitrogen fertigation on plant height, leaf length, fresh and dry weight of onion leaves. The experiment was laid out with four levels of drip irrigation $(60,80,100$ and $120 \%$ of CPE) as main plots and four levels of nitrogen fertigation $(75,100,125$ and $150 \mathrm{~kg} / \mathrm{ha})$ as sub plots in a Split Plot Design and replicated three times with one control (surface irrigation and recommended dose of fertilizers). The seedlings of onion cv. Hisar Onion 4 were transplanted at $15 \times 10 \mathrm{~cm}$ spacing in first week of January during both years. The maximum plant height (56.77 and $53.05 \mathrm{~cm})$, leaf length $(38.26$ and $36.42 \mathrm{~cm})$, fresh $(38.36$ and $37.59 \mathrm{~g})$ and dry $(4.69$ and $5.46 \mathrm{~g}$ ) weight of leaves per plant were recorded under drip irrigation at $120 \%$ CPE as compared to other levels of drip irrigation, while the lowest plant height (41.66 and 44.39 $\mathrm{cm})$ and leaf length $(24.59$ and $25.40 \mathrm{~cm})$, fresh $(21.98$ and $27.56 \mathrm{~g})$ and dry $(2.40$ and 3.56 g) weight of leaves per plant were observed with the drip irrigation at $60 \%$ CPE during both years, respectively. Among the different levels of nitrogen fertigation, plant height $(56.10$ and $52.20 \mathrm{~cm})$, leaf length $(37.78$ and $36.18 \mathrm{c} \mathrm{cm})$, fresh $(34.34$ and $38.44 \mathrm{~g})$ and dry ( 4.21 and $5.76 \mathrm{~g}$ ) weight of leaves per plant were observed maximum with the application of $150 \mathrm{~kg} / \mathrm{ha}$ nitrogen through drip as compared to other levels of nitrogen fertigation, respectively. Interaction of irrigation and nitrogen fertigation also significantly affected the leaf length, fresh and dry weight of onion leaves per plant but the plant height did not differed significantly with the combined application of drip irrigation and nitrogen fertigation in both years.

\section{Introduction}

Onion (Allium cepa L.) belonging to the family Alliaceae is one of the most important bulb as well as cash crops of the world. Onion is considered second most important vegetable crop grown in the world after tomato. The primary centre of origin of onions lies in central Asia, while the Near East and the Mediterranean is the secondary centre of origin. It can be eaten raw in salad, fried, boiled or roasted and used in flavoring soups, canned food products and in preparation of different dishes (Gambo et al., 2008). The 
pungency in onion is due to volatile oil allylpropyl disulphide and skin colour is due to presence of quercetin. Amongst the onion producing countries in the world, India ranks second in area and production after China and third in export after Netherland and Spain. In India, it is grown on 1.32 million hectare area with annual production of 20.93 million tonnes worth Rs. 3,7235.62 crore during 201516. Similarly, in Haryana the area under onion crop is 30.65 thousand hectare with production of 705.80 thousand tones and average productivity of 23.03 tonnes per hectare (Anonymous, 2015).

Onion is most sensitive to water stress because of very shallow root system, hence, it requires frequent irrigations as compared to other vegetable crops since water stress particularly at bulb development stage, which usually coincides with summer season, affects the yield drastically. Under such circumstances, drip irrigation is a promising technology by which limited water is applied at low pressure near the root zone of the plant (Chopde and Bansode, 1995). Michael (1978) reported that it is one of the latest systems, becoming popular in areas where the scarcity of water and salinity is a major problem. Because of their shallow and unbranched root system, onion and other Alliums are less efficient in extracting moisture and nutrients from the soil as compared to many crops. Hence, frequent application of nutrients and pesticides during the crop-growing period through micro irrigation system is essential for higher production, quality, water and nutrient use efficiency and economic return. This makes moisture and nitrogen management a key factor in its production (Kebede, 2003).

\section{Materials and Methods}

The field experiments were conducted during the Rabi seasons of 2016-17 and 2017-18 at Research Farm of the Department of
Vegetable Science, CCS Haryana Agricultural University, Hisar to study the effect of irrigation and nitrogen levels on growth and yield parameters of onion under drip irrigation system. The soil of the experimental site was sandy loam in texture, slightly high in $\mathrm{pH}$, low in organic carbon and available nitrogen, medium in available phosphorus and high in available potash. The seedlings of onion variety Hisar Onion 4 were transplanted at 15 $\mathrm{x} 10 \mathrm{~cm}$ spacing during the first week of January in both years. The experiment was laid out in Split Plot Design with three replications comprised of four irrigation levels, viz., 60, 80, 100 and $120 \%$ of cumulative pan evaporation (CPE) as main plots and four nitrogen levels, viz., 75, 100, 125 and $150 \mathrm{~kg} / \mathrm{ha}$ as sub plots and conventional irrigation as absolute control. The recommended dose of phosphorus and potassium fertilizers $(50: 25 \mathrm{~kg} / \mathrm{ha} \mathrm{PK})$ was applied during bed preparation as basal application. A common and light irrigation was given just after transplanting of seedling for uniform and better establishment of crop. Irrigation water was applied through drip irrigation to the various treatments according to the daily pan evaporation reading when the $10 \mathrm{~mm}$ of cumulative pan evaporation (CPE) was occurred and application of various levels of nitrogen was given in five splits at 15 days interval through fertigation. The data recorded on different parameters were subjected to statistical analysis and the mean differences were evaluated by critical difference (CD) test at $5 \%$ level of significance.

\section{Results and Discussion}

The plant height and leaf length was significantly influenced with the different levels of drip irrigation and nitrogen fertigation in both years. Among the different levels of drip irrigation, the growth parameters like plant height and leaf length was increased with the increasing levels of drip irrigation 
from 60 to $120 \%$ CPE during 2016-17 and 2017-18. The maximum plant height (56.77 and $53.05 \mathrm{~cm}$, respectively) and leaf length (38.26 and $36.42 \mathrm{~cm}$, respectively) was recorded with the drip irrigation at $120 \% \mathrm{CPE}$ followed by $100 \% \mathrm{CPE}$, while the lowest plant height (41.66 and $44.39 \mathrm{~cm}$, respectively) and leaf length (24.59 and $25.40 \mathrm{~cm}$, respectively) was found at $60 \%$ CPE in both years (Table 1 and 2). The increase in plant height with the increase in quantity of irrigation water might be due to favorable effect of water in maintaining the turgor pressure of cell, which is the major prerequisite for growth (Vaux and Pruit, 1983). On the contrary, shortening of plant height under moisture stress may be due to closing of stomata and reduced $\mathrm{CO}_{2}$ and nutrients uptake by plants. Hence, photosynthesis and other biochemical processes are stopped and affected plant growth (EI-Noemani et al., 2009). These results are in agreement with the finding of Mallikarjun et al., (2011), Bagali et al., (2012) in onion and Der et al., (2018) in garlic. Among the nitrogen fertigation levels, the plant height and leaf length was also increased with the increasing levels of nitrogen fertigation from 75 to $150 \mathrm{~kg} / \mathrm{ha}$ during both the years of study.

The maximum plant height (56.10 and 52.20 $\mathrm{cm})$ and leaf length (37.78 and $36.18 \mathrm{~cm}$ ) was observed with the application of $150 \mathrm{~kg} / \mathrm{ha}$ nitrogen through drip irrigation as compared to other levels of nitrogen, whereas, the minimum plant height $(21.44$ and $21.93 \mathrm{~cm})$ and leaf length was recorded where the 75 $\mathrm{kg} / \mathrm{ha}$ nitrogen was applied through drip irrigation in both years, respectively. This could be due to nitrogen fertilization accelerated synthesis of chlorophyll, amino acids and encouraged greater green leaf area helping in higher carbohydrate synthesis and build up of new cells, which might have contributed for higher growth. Kebede (2003) reported that too much nitrogen promoted excessive plant height of onion crop. Prabhakar et al., (2011) and Kakade et al., (2015) also observed that the positive effect of nitrogen fertigation on crop growth as compared to soil application method.

Table.1 Effect of irrigation and nitrogen levels on plant height $(\mathrm{cm})$ of onion

\begin{tabular}{|c|c|c|c|c|c|c|c|c|c|c|c|}
\hline \multirow{3}{*}{$\begin{array}{c}\text { Irrigation } \\
\text { (\% CPE) }\end{array}$} & \multicolumn{5}{|c|}{ 2016-17 } & \multicolumn{6}{|c|}{ 2017-18 } \\
\hline & \multicolumn{5}{|c|}{ Nitrogen (kg/ha) } & \multicolumn{6}{|c|}{ Nitrogen (kg/ha) } \\
\hline & $\begin{array}{c}N_{1} \\
(75)\end{array}$ & $\begin{array}{c}N_{2} \\
(100)\end{array}$ & $\begin{array}{c}\mathbf{N}_{3} \\
(\mathbf{1 2 5})\end{array}$ & $\begin{array}{c}\mathbf{N}_{4} \\
(150)\end{array}$ & Mean & $\begin{array}{c}N_{1} \\
(75)\end{array}$ & $\begin{array}{c}\mathbf{N}_{2} \\
(\mathbf{1 0 0})\end{array}$ & $\begin{array}{c}N_{3} \\
(\mathbf{1 2 5})\end{array}$ & \multicolumn{2}{|c|}{$\begin{array}{c}\mathbf{N}_{4} \\
(\mathbf{1 5 0})\end{array}$} & Mean \\
\hline$I_{1}(60)$ & 34.45 & 39.11 & 44.11 & 48.97 & 41.66 & 36.78 & 43.44 & 47.67 & \multicolumn{2}{|c|}{49.67} & 44.39 \\
\hline $\mathbf{I}_{2}(\mathbf{8 0})$ & 42.89 & 49.80 & 50.22 & 54.07 & 49.24 & 45.22 & 50.00 & 51.37 & \multicolumn{2}{|c|}{52.35} & 49.74 \\
\hline$I_{3}(\mathbf{1 0 0})$ & 46.44 & 51.22 & 59.40 & 56.64 & 53.43 & 46.44 & 51.58 & 53.48 & \multicolumn{2}{|c|}{50.30} & 50.45 \\
\hline $\mathrm{I}_{4}(\mathbf{1 2 0})$ & 47.53 & 53.28 & 61.57 & 64.71 & 56.77 & 48.78 & 52.07 & 54.88 & \multicolumn{2}{|c|}{56.48} & 53.05 \\
\hline Mean & 42.83 & 48.35 & 53.82 & \multicolumn{2}{|c|}{56.10} & 44.31 & 49.27 & 51.85 & \multicolumn{2}{|c|}{52.20} & \\
\hline Control & \multicolumn{5}{|c|}{43.74} & \multicolumn{6}{|c|}{45.58} \\
\hline Factors & I & $\mathbf{N}$ & \multicolumn{2}{|c|}{$\begin{array}{l}\mathrm{N} \text { at same } \\
\text { level of I }\end{array}$} & $\begin{array}{l}\text { I at same } \\
\text { level of } N\end{array}$ & I & $\mathbf{N}$ & \multicolumn{2}{|c|}{$\begin{array}{l}N \text { at same } \\
\text { level of I }\end{array}$} & \multicolumn{2}{|c|}{$\begin{array}{l}\text { I at same } \\
\text { level of } \mathbf{N}\end{array}$} \\
\hline $\mathrm{SE}(\mathbf{m}) \pm$ & 0.44 & 0.73 & \multicolumn{2}{|c|}{0.88} & 1.34 & 0.53 & 0.67 & \multicolumn{2}{|c|}{1.07} & \multicolumn{2}{|c|}{1.28} \\
\hline CD at $5 \%$ & 1.54 & 2.15 & \multicolumn{2}{|c|}{ NA } & NA & 1.88 & 1.97 & \multicolumn{2}{|c|}{ NA } & \multicolumn{2}{|c|}{ NA } \\
\hline
\end{tabular}


Table.2 Effect of irrigation and nitrogen levels on leaf length $(\mathrm{cm})$ of onion plant

\begin{tabular}{|c|c|c|c|c|c|c|c|c|c|c|c|}
\hline \multirow{3}{*}{$\begin{array}{l}\text { Irrigation } \\
\text { (\% CPE) }\end{array}$} & \multicolumn{6}{|c|}{ 2016-17 } & \multicolumn{5}{|c|}{ 2017-18 } \\
\hline & \multicolumn{6}{|c|}{ Nitrogen (kg/ha) } & \multicolumn{5}{|c|}{ Nitrogen (kg/ha) } \\
\hline & $\begin{array}{c}N_{1} \\
(75)\end{array}$ & $\begin{array}{c}\mathbf{N}_{2} \\
(100)\end{array}$ & $\begin{array}{c}N_{3} \\
\text { (125) }\end{array}$ & $\begin{array}{r}N \\
(15\end{array}$ & & Mean & $\begin{array}{c}N_{1} \\
(75)\end{array}$ & $\begin{array}{c}\mathbf{N}_{2} \\
(100)\end{array}$ & $\begin{array}{c}N_{3} \\
(\mathbf{1 2 5})\end{array}$ & $\begin{array}{c}\mathbf{N}_{4} \\
(150)\end{array}$ & Mean \\
\hline$I_{1}(60)$ & 18.57 & 25.13 & 26.93 & 27. & & 24.59 & 19.44 & 25.69 & 27.92 & 28.55 & 25.40 \\
\hline$I_{2}(80)$ & 20.62 & 29.29 & 30.46 & 33. & & 28.56 & 21.92 & 29.76 & 29.81 & 31.52 & 28.25 \\
\hline$I_{3}(\mathbf{1 0 0})$ & 22.29 & 32.25 & 37.72 & 40. & & 33.20 & 22.44 & 31.99 & 32.56 & 39.30 & 31.57 \\
\hline$I_{4}(120)$ & 24.30 & 35.79 & 43.98 & 48. & & 38.26 & 23.92 & 36.24 & 40.19 & 45.35 & 36.42 \\
\hline Mean & 21.44 & 30.62 & 34.77 & 37. & & & 21.93 & 30.92 & 32.62 & 36.18 & \\
\hline Control & \multicolumn{6}{|c|}{25.35} & \multicolumn{5}{|c|}{26.74} \\
\hline Factors & I & $\mathbf{N}$ & \multicolumn{2}{|c|}{$\begin{array}{c}N \text { at same } \\
\text { level of I }\end{array}$} & \multicolumn{2}{|c|}{$\begin{array}{l}\text { I at same } \\
\text { level of } N\end{array}$} & I & $\mathbf{N}$ & \multicolumn{2}{|c|}{$\begin{array}{l}N \text { at same } \\
\text { level of I }\end{array}$} & $\begin{array}{l}\text { at same } \\
\text { evel of } N\end{array}$ \\
\hline SE $(m) \pm$ & 0.75 & 0.88 & 1.5 & & 1.6 & & 0.66 & 0.78 & 1.32 & & 1.53 \\
\hline CD at $5 \%$ & 2.67 & 2.79 & 4.3 & & 4.5 & & 2.31 & 2.34 & 4.91 & & 4.74 \\
\hline
\end{tabular}

Table.3 Effect of irrigation and nitrogen levels on fresh weight of onion leaves per plant (g)

\begin{tabular}{|c|c|c|c|c|c|c|c|c|c|c|}
\hline \multirow{3}{*}{$\begin{array}{l}\text { Irrigation } \\
\text { (\% CPE) }\end{array}$} & \multicolumn{5}{|c|}{ 2016-17 } & \multicolumn{5}{|c|}{ 2017-18 } \\
\hline & \multicolumn{5}{|c|}{ Nitrogen (kg/ha) } & \multicolumn{5}{|c|}{ Nitrogen (kg/ha) } \\
\hline & $\begin{array}{l}N_{1} \\
(75)\end{array}$ & $\begin{array}{c}\mathbf{N}_{2} \\
(100)\end{array}$ & $\begin{array}{c}\mathbf{N}_{3} \\
(\mathbf{1 2 5})\end{array}$ & $\begin{array}{c}\mathbf{N}_{4} \\
(\mathbf{1 5 0})\end{array}$ & Mean & $\begin{array}{l}N_{1} \\
(75)\end{array}$ & $\begin{array}{c}\mathbf{N}_{2} \\
(\mathbf{1 0 0})\end{array}$ & $\begin{array}{c}\mathrm{N}_{3} \\
(\mathbf{1 2 5})\end{array}$ & $\begin{array}{c}\mathbf{N}_{4} \\
(150)\end{array}$ & Mean \\
\hline$I_{1}(60)$ & 18.13 & 20.33 & 22.74 & 26.72 & 21.98 & 22.42 & 25.56 & 29.52 & 32.75 & 27.56 \\
\hline$I_{2}(\mathbf{8 0})$ & 21.40 & 25.30 & 28.60 & 30.66 & 26.49 & 26.00 & 30.95 & 33.04 & 35.80 & 31.45 \\
\hline $\mathbf{I}_{\mathbf{3}}(\mathbf{1 0 0})$ & 27.93 & 31.25 & 35.27 & 37.14 & 32.90 & 28.78 & 34.46 & 38.94 & 41.80 & 36.00 \\
\hline $\mathrm{I}_{4}(\mathbf{1 2 0})$ & 32.32 & 37.66 & 40.60 & 42.85 & 38.36 & 31.76 & 35.78 & 39.42 & 43.42 & 37.59 \\
\hline Mean & 24.95 & 28.64 & 31.80 & 34.34 & & 27.24 & 31.69 & 35.23 & 38.44 & \\
\hline Control & \multicolumn{5}{|c|}{22.61} & \multicolumn{5}{|c|}{29.74} \\
\hline Factors & I & $\mathbf{N}$ & $\begin{array}{l}N \text { at same } \\
\text { level of I }\end{array}$ & \multicolumn{2}{|c|}{$\begin{array}{l}\text { I at same } \\
\text { level of } N\end{array}$} & I & $\mathbf{N}$ & \multicolumn{2}{|l|}{$\begin{array}{l}\mathrm{N} \text { at same } \\
\text { level of } \mathrm{I}\end{array}$} & $\begin{array}{l}\text { I at same } \\
\text { level of } N\end{array}$ \\
\hline $\mathrm{SE}(\mathrm{m}) \pm$ & 0.38 & 0.37 & 0.78 & 0.7 & & 0.19 & 0.27 & 0.39 & & 0.51 \\
\hline CD at $5 \%$ & 1.13 & 1.14 & 2.21 & 2.08 & & 0.68 & 0.80 & 1.65 & & 1.55 \\
\hline
\end{tabular}

Table.4 Effect of irrigation and nitrogen levels on dry weight of onion leaves per plant $(\mathrm{g})$

\begin{tabular}{|c|c|c|c|c|c|c|c|c|c|c|}
\hline \multirow{3}{*}{$\begin{array}{l}\text { Irrigation } \\
\text { (\% CPE) }\end{array}$} & \multicolumn{5}{|c|}{ 2016-17 } & \multicolumn{5}{|c|}{ 2017-18 } \\
\hline & \multicolumn{5}{|c|}{ Nitrogen (kg/ha) } & \multicolumn{5}{|c|}{ Nitrogen (kg/ha) } \\
\hline & $\begin{array}{l}N_{1} \\
(75)\end{array}$ & $\begin{array}{c}\mathbf{N}_{2} \\
(\mathbf{1 0 0})\end{array}$ & $\begin{array}{c}\mathbf{N}_{3} \\
(\mathbf{1 2 5})\end{array}$ & $\begin{array}{c}\mathbf{N}_{4} \\
(\mathbf{1 5 0})\end{array}$ & Mean & $\begin{array}{l}N_{1} \\
(75)\end{array}$ & $\begin{array}{c}\mathbf{N}_{2} \\
(\mathbf{1 0 0})\end{array}$ & $\begin{array}{c}\mathbf{N}_{3} \\
(\mathbf{1 2 5})\end{array}$ & $\begin{array}{c}\mathbf{N}_{4} \\
(\mathbf{1 5 0})\end{array}$ & Mean \\
\hline$I_{1}(60)$ & 1.80 & 2.15 & 2.54 & 3.09 & 2.40 & 2.53 & 3.25 & 3.88 & 4.59 & 3.56 \\
\hline $\mathbf{I}_{2}(\mathbf{8 0})$ & 2.16 & 2.75 & 3.25 & 3.62 & 2.94 & 3.28 & 4.10 & 4.67 & 5.23 & 4.32 \\
\hline$I_{3}(\mathbf{1 0 0})$ & 2.92 & 3.52 & 4.06 & 4.50 & 3.75 & 3.74 & 4.66 & 5.67 & 6.45 & 5.13 \\
\hline $\mathbf{I}_{4}(\mathbf{1 2 0})$ & 3.57 & 4.49 & 5.05 & 5.64 & 4.69 & 4.18 & 5.07 & 5.81 & 6.76 & 5.46 \\
\hline Mean & 2.61 & 3.23 & 3.73 & 4.21 & & 3.43 & 4.27 & 5.01 & 5.76 & \\
\hline Control & \multicolumn{5}{|c|}{2.60} & \multicolumn{5}{|c|}{3.72} \\
\hline Factors & I & $\mathbf{N}$ & $\begin{array}{l}\mathbf{N} \text { at same } \\
\text { level of I }\end{array}$ & \multicolumn{2}{|c|}{$\begin{array}{l}\text { I at same } \\
\text { level of } N\end{array}$} & I & $\mathbf{N}$ & \multicolumn{2}{|c|}{$\begin{array}{l}\mathbf{N} \text { at same } \\
\text { level of I }\end{array}$} & $\begin{array}{l}\text { I at same } \\
\text { level of } N\end{array}$ \\
\hline $\mathrm{SE}(\mathrm{m}) \pm$ & 0.07 & 0.08 & 0.13 & \multicolumn{2}{|c|}{0.14} & 0.06 & 0.06 & \multicolumn{2}{|l|}{0.11} & 0.12 \\
\hline CD at $5 \%$ & 0.23 & 0.28 & 0.45 & \multicolumn{2}{|c|}{0.44} & 0.20 & 0.18 & \multicolumn{2}{|l|}{0.37} & 0.36 \\
\hline
\end{tabular}


Interaction effect of drip irrigation and nitrogen fertigation had not significant effect on plant height in both years but the leaf length was significantly influenced with the interaction between drip irrigation and nitrogen fertigation in both years. The maximum leaf length (48.95 and $45.35 \mathrm{~cm}$ ) was recorded with drip irrigation at $120 \%$ $\mathrm{CPE}$ and $150 \mathrm{~kg} / \mathrm{ha}$ nitrogen fertigation followed by drip irrigation at $100 \% \mathrm{CPE}$ with $125 \mathrm{~kg} / \mathrm{ha}$ nitrogen fertigation, while, the minimum leaf length $(25.35$ and $26.74 \mathrm{~cm})$ was found where the drip irrigation was given at $60 \% \mathrm{CPE}$ in combination with $75 \mathrm{~kg} / \mathrm{ha}$ nitrogen application through drip irrigation during both years of investigation, respectively. This might be due to better availability of moisture and nutrients during the entire growth period, which favoured the growth parameters resulting in better photosynthesis and accumulation of photosynthates. These findings are in agreement with Kemal (2013) in shallot and Gebregwergis et al., (2015) in onion.

Fresh and dry weight of leaves per plant was significantly influenced with the different levels of drip irrigation and nitrogen fertigation in both years (Table 3 and 4). The fresh and dry weight of leaves per plant was increased with the increasing levels of drip irrigation from 60 to $120 \%$ CPE during both years of study. The drip irrigation at $120 \%$ CPE gave the maximum fresh (38.36 and $37.59 \mathrm{~g})$ and dry (4.69 and $5.46 \mathrm{~g}$ ) weight of leaves as compared to other drip irrigation levels, whereas, the minimum fresh $(21.98$ and $27.56 \mathrm{~g}$ ) and dry (2.40 and $3.56 \mathrm{~g}$ ) weight of leaves was obtained from $60 \%$ CPE in both years, respectively. Among the different levels of nitrogen fertigation, the maximum fresh (34.34 and $38.44 \mathrm{~g}$, respectively) and dry (4.21 and $5.76 \mathrm{~g}$, respectively) weight of leaves was found at $150 \mathrm{~kg} / \mathrm{ha}$ nitrogen fertigation followed by $125 \mathrm{~kg} / \mathrm{ha}$ nitrogen fertigation, while the minimum fresh $(24.95$ and $27.24 \mathrm{~g}$, respectively) and dry (2.61 and $3.43 \mathrm{~g}$, respectively) weight of leaves was recorded with the application of $75 \mathrm{~kg} / \mathrm{ha}$ nitrogen through drip during both the years. The interaction of drip irrigation and nitrogen fertigation also significantly influenced the fresh and dry weight of leaves in both years. The highest fresh (42.85 and $43.42 \mathrm{~g}$, respectively) and dry (5.64 and $6.76 \mathrm{~g}$, respectively) weight of leaves was calculated under drip irrigation at $120 \%$ CPE with 150 $\mathrm{kg} / \mathrm{ha}$ nitrogen fertigation during both the years of investigation. The increase in fresh and dry weight of leaves with the increasing levels of irrigation and nitrogen might be due to the facts that improvement of water and nutrients availability near the root zone and its enhancing effect on crop's biological function, which improves the growth of the crop; consequently, increased the fresh and dry weight of the leaves. This result is similar with the findings of Ewais et al., (2010) and Kakade et al., (2015).

\section{References}

Anonymous, 2015. National Horticulture Research and Development Foundation, Nashik (www.nhrdf.com).

Bagali, A.N., Patil, H.B., Guled, M.B. and Patil, R.V. 2012. Effect of scheduling of drip irrigation on growth, yield and water use efficiency of onion (Allium cepa L.). Karnataka Journal of Agriculture Science, 25 (1): 116-119.

Chopde, S.O. and Bansode, P.N. 1995. Response of liquid fertilizer by trickle irrigation to onion (Allium cepa L.). B.Tech. project report (Agril. Engg), Dr. Punjabrao Deshmukh Krishi Vidyapeeth, Akola (M.S.).

Der, H.N., Dabhi, A.B., Barad, B.B. and Gohil, P.J. 2018. Scheduling of drip irrigation and fertigation in rabi garlic (Allium sativum L.). International Journal of Chemical Studies, 6(3): 
1002-1005.

El-Noemani, A. Aboamera, O.M. Aboellil and Dewedar, 2009. Growth, yield, quality and water use efficiency of pea plant as affected by evapotranspiration and sprinkler height. Journal of Agricultural Research, 34: 1445-1466.

Ewais, M.A., Mahmoud, A.A. and Khalil, A.A. 2010. Effect of nitrogen fertigation in comparison with soil application on onion production in sandy soils. Alexandria Journal of Agricultural Research, 55: 75-83.

Gambo, B.A., Magaji, M.D., Yakubu, A.I. and Dikko, A.U. 2008. Effect of FYM, Nitrogen and weed interference on the growth and yield of onion (Allium cepa L.) at Sokto Rima Valley. Journal of Sustainable Development in Agricultural and Environment, 3(2): 8792.

Gebregwergis, F., Kebede, W. and Yibekal, A. 2015. Effect of irrigation depth and nitrogen levels on growth and bulb yield of onion (Allium cepa L.) at Algae, Central Rift Valley of Ethiopia. International Journal of Life Sciences, 5(3): 152-162.

Kakade, S.U, Bhale, V.M. and Deshmukh, J.P. 2015. Effect of split application of nutrients through fertigation on growth, yield and quality of onion. International
Journal of Tropical Agriculture, 33(4): 3279-3283.

Kebede, W. 2003. Shallot (Allium cepa var. ascalonicum) responses to plant nutrient and soil moisture in a sub-humid tropical climate. Journal of Horticultural sciences and Biotechnology, 78(4): 549-555.

Kemal, Y.O. 2013. Effects of irrigation and nitrogen levels on bulb yield, nitrogen uptake and water use efficiency of shallot (Allium cepa var. ascalonicum). African Journal of Agricultural Research, 8(37): 4637-4643.

Mallikarjun, R., Ayyanagowdar, M.S., Nemichandrappa, M., Momin, U., Horaginamani, M. and Ravichandran, M. 2011. Influence of drip irrigation methods on growth and yield of onion at Raichur region. Indian Journal of Natural Sciences, 11(8):580-587.

Michael, A.M., 1978. Irrigation Theory and Practices. Second reprint. Vikas Publishing House Pvt. Ltd.

Prabhakar, M., Hebbar, S.S. and Nair, A.K. 2011. Effect of microsprinkler fertigation on growth and yield of rabi onion. Journal of Horticulture Science, 6(1): 66-68.

Vaux, H. J. and Pruit, W.O. 1983. Crop water production function. In: D. Hillel (Ed). Advance Irrigation, 12:16-93.

\section{How to cite this article:}

Pooja Rani, V.K. Batra, A.K. Bhatia and Shiwani. 2018. Influence of Drip Irrigation and Nitrogen Fertigation on Growth Parameters of Onion (Allium cepa L.). Int.J.Curr.Microbiol.App.Sci. 7(12): 2946-2951. doi: https://doi.org/10.20546/ijcmas.2018.712.336 